\title{
A TESSITURA IRÔNICA DE A QUEDA DUM ANJO, DE CAMILO CASTELO BRANCO
}

\author{
Lélia Parreira Duarte
}

UFMG

L'ironie fait et défait sans cesse sa tapisserie de Penélope, son ouvrage perpétuellement naissant.

(Jankélévitch)

Eu digo ao leitor o que as mães dos recémnascidos dizem aos filhos mais velhos: "Vieram de França numa condessinha".

(Camilo Castelo Branco)

Camilo Castelo Branco é uma personalidade literária vista como ímpar pelos estudiosos de Literatura Portuguesa: pela fecundidade de sua pena e pela qualidade de seus escritos, pela maleabilidade e flexibilidade de seus mundos, por seu domínio retórico da língua e pelo ritmo que imprime ao todo organizado de cada uma de suas novelas. Em 1990 celebrou-se o centenário de morte do escritor, mas ainda hoje estamos mergulhados nas fe- 
cundas comemorações de que resultaram interessantes e instigantes estudos de sua obra. Entre esses ocupam certamente lugar de destaque os que privilegiam a questão da ironia, referida, de alguma forma, por todos aqueles que se debruçam sobre os textos camilianos.

Este artigo pretende apontar a presença da ironia em uma narrativa camiliana $-A$ queda dum an$j o$, em que um narrador/autor aponta para o leitor atento os fios da dupla trama irônica com que busca estabelecer comunicação. Para isso tenta observar alguns sinais de ironia na novela, tecer considerações sobre romantismo e ironia e sobre o ironista Camilo, para depois analisar a sátira social e as artes \& manhas da enunciação do texto.

$A$ queda dum anjo é uma narrativa ambígua, construída com o fio evanescente da ironia, por um emissor/artífice que parece usar o que Guido Almansi chama de tongue-in-cheek ${ }^{2}$, ou seja, múltiplos e sutis sinais dirigidos ao receptor, a lhe indicar a necessidade de cuidado na leitura. Se ficar atento, o leitor poderá perceber que, além de relatar a história de Calisto Elói de Silos e Benevides de Barbuda, criticar o contexto que retrata e as modas literárias de seu tempo, a novela torna visível o material que utiliza e a ironia romântica com que se constrói, enquanto se constitui numa forma de comunicação entre autor e leitor e atribui a este a responsabilidade de uma leitura ativa e coadjuvante da construção do sentido do texto.

A novela apresenta simultaneamente traços românticos e ultra-românticos, ao lado de críticas à produção e à recepção da obra romântica, indicadas principalmente através da incongruência de elementos incompatíveis colocados lado a lado. Essa contradição faz com que se esvazie a emoção que seria provocada pelos elementos passionais presentes na novela, revelando assim a sua intenção paródica e a sua tessitura irônica.

Um exemplo disso é a "queda do anjo", que não será exatamente de um anjo e nem realmente uma queda, ou será uma queda às avessas, uma espécie

1. BRANCO, 1981.

2. ALMANSI, 1978. p. 413 - 426. de jogo de perde-ganha, pois depois dela o protagonista sobe aos céus, como a ninfa que tem o seu nome - Calisto -, mas também desce à terra, já que se humaniza: deixa de ser um anjo infeliz para tornar-se o que a ideologia considera um homem feliz, "com algumas vantagens a mais que o comum dos homens". Isso aliás se indica em seu pomposo e ambíguo nome - Calisto Elói de Silos e Benevides de Barbuda.

Esse nome marca positivamente a personagem, pois Calisto é o superlativo de kalós, sendo portanto, o mais belo; Elói é o escolhido, o eleito, além de lembrar Eloim, nome que substitui muitas vezes o de Jeová no Pentateuco e poderia ser visto como indicador de um ser que está em contato com Deus. Silos lembraria o grego síros (sátira, poema satírico, paródia); refere também tulha, depósito, de onde a idéia de armazenamento e/ou entulhamento de riquezas e de erudição. Benevides, como o texto explica, seria aquele que vive bem, sendo etimologicamente o que vê bem ${ }^{3}$; e Barbuda é família importante, com brasão, armas e timbre. Fazendo jus ao nome, Calisto Elói é bom filho e, principalmente, é morgado - herdeiro da fortuna familiar - , aumentada por ele a partir do casamento com o "dom de Deus" Teodora. Seu ofício/mania eram os livros antigos, nos quais encontrava prazer, lei e verdade incontestáveis, talvez porque assim se confirmava a sua situação de poder.

Calisto é também o sujeito que encalista - dá azar ao jogador: esse sinal de má sorte atinge realmente aqueles que se opõem à personagem, ou o leitor que lê ingenuamente a novela.

A trajetória do morgado de Agra das Freimas, ao contrário, é sempre assinalada por elementos positivos, sendo as suas decepções - especialmente a frustração amorosa com Adelaide - resultado de seus problemas de leitura, mas também sinais

3. Esse significado para Benevides, a partir da etimologia do nome, foi lembrado pela Profa. Ângela Vaz Leão como uma contribuição a este trabalho, inicialmente apresentado como seminário ao concurso para professor titular de Literatura Portuguesa na FALE/UFMG. 
de sua passagem para uma situação de privilégios especiais.

Marcado positivamente através de seus elementos constitutivos, o nome da personagem opõe-se entretanto à sua caracterização inicial, pois a descrição de sua figura, numa oposição que sinaliza a ironia, apresenta traços grosseiros e ridículos. $\mathrm{O}$ narrador afirma errar o leitor que enquadrar a personagem em molde grotesco; apresenta-a, entretanto, vestindo em 1865 o mesmo tipo de roupa com que se casara em 1833 e assim a descreve: "sensível e dessimétrica saliência do abdômen", "nariz um tanto estragado das invasões do rapé e torceduras do lenço de algodão vermelho" (p. 50) e tronco com tal qual inclinação, "que denunciava o arqueamento da espinha por efeito da incansável leitura e minguado exercício" (p. 51). Calisto Elói é uma figura quixotesca: leitor inveterado, acredita que as obras literárias imitam e representam a realidade. Por isso procura seguir a tradição ao pé da letra e busca na "vida real" o que lê nos livros, encontrando muitas decepções em sua ida para Lisboa.

Em sua trajetória na capital a personagem conhece Adelaide, a de "porte nobre", que funciona como Ariadne ao fornecer-lhe o fio do amor, embora seja causa também de sua primeira frustração amorosa. E' após essa iniciação que Calisto encontra Ifigênia, a "nascida com o poder", que não tem fortuna mas beleza e experiência (e esperteza) capazes de garantir ao deputado a saída de sua labiríntica e livresca prisão. Desde o momento em que ouve falar da brasileira, Calisto esquece a desilusão amorosa sofrida com Adelaide, assim como qualquer problema de consciência com relação ao seu adultério.

$E^{\prime}$ portanto após a queda, isto é, depois de passar pelo ritual de iniciação/frustração no amor, que Calisto Elói passa a ser dono de uma bela figura e a fazer jus a seu nome: perde a barriga, desempena o corpo, passa a vestir-se nos melhores alfaiates, deixa crescer a barba e faz outras "reformas capilares"; troca o rapé pelo charuto, os óculos pela luneta, manda queimar as críticas que escrevera contra o luxo, compra magníficas alfaias es- trangeiras e completa a transformação com uma viagem à Europa. Encerra, além disso, a sua carreira de orador prolixo e de reformador do mundo e, com a intenção de receber apoio para a reeleição, arranja o esperado hábito de Cristo para o mestre-escola e para o boticário, mudando posteriormente de partido político para obter vantagens no governo. Calisto Elói de Silos e Benevides de Barbuda integra-se assim realisticamente na civilização e aprende a usufruir de suas riquezas e dos prazeres da vida: ama uma linda mulher que o preza muito e the dá duas lindas crianças loiras que são "penhores de felicidade infinita"; atualiza suas leituras, passa a ter boa vida cultural também fora dos livros, e além de tudo torna-se barão, o que indica sua integração na sociedade de seu tempo.

$A$ queda dum anjo parodia assim o modelo tradicional das novelas passionais do próprio Camilo Castelo Branco, em que os amantes são geralmente separados pela sociedade e morrem - assassinados, doentes ou mortos em vida em conventos ou hospícios - , ou enfrentam a oposição social, sem encontrar a felicidade. A novela inverte ironicamente a questão: parte de uma união abençoada pela Igreja e pela sociedade e efetivada em consonância com as exigências de ambas, já que Calisto e Teodora teriam o mesmo nivel social e econômico; orienta em seguida a intriga ficcional para a realização do amor fora do casamento, como se procurasse até ignorar esse contrato social. $E^{\prime}$ interessante observar, nesse sentido, o nome da rua onde mora Ifigênia: de São João dos Bem-Casados.

Poder-se-ia ver nesses elementos a ironia como sátira a uma sociedade que reprime e condena o amor ilícito do próprio Camilo, ou reprova o amor apenas quando uma classe mais alta tem ameaçado o seu poder econốmico, a partir do desejo amoroso de um elemento de classe inferior, como acontece em várias novelas camilianas (Amor de perdiçâo, Carlota Angela, A doida do Candal, Onde está a felicidade e outras). Haveria aí, por extensão, um irônico alerta ao leitor, que só poderá assumir a valorização romântica do eu e da liberdade na medida em que se posicionar critica- 
mente diante da realidade. Mas poder-se-ia ver também na novela a presença de uma ironia que procura mostrar ao leitor a necessidade de leitura atenta, capaz de perceber os artifícios de construção de um texto que procura exibir o seu caráter enganoso de trama e jogo. $\mathrm{E}$, principalmente, poder-se-ia ver aí uma indireta valorização da literatura, da leitura e, enfim, da comunicação, através das quais o homem pode ter momentaneamente a plenitude e a liberdade.

O enunciado de $A$ queda dum anjo é elaborado com dados do Romantismo - ou seja, valorização do Eu, do amor, da liberdade individual e da vida -, mas também com elementos do Realismo, pois evidencia o pragmatismo de personagens que se adaptam ao contexto, procurando dele tirar proveito. No plano da enunciação, observa-se que a novela apresenta um narrador que, interrompendo a cada momento a diegese com seus comentários, dirigidos a um receptor intradiegético, destrói com a parábase a ilusão do texto como representação da realidade e resultado de inspiração. Mostra-o assim como produção de uma inteligência criadora, que esvazia a seriedade a partir do jogo, usando elementos de representação e fingimento na construção de personagens, situações e discursos e configurando o que se convencionou chamar ironia romântica. O autor emparelha a sua arte assim com a capacidade de percepção do leitor, revelando a consciência de que somente a existência desse outro torna real a sua obra e, afinal, a sua própria existência.

Uma das distinções que se pode estabelecer entre literatura clássica e romântica parece ter como base o uso da ironia, pois no Classicismo a postura do autor literário (e do artista em geral) é a daquele que está imbuído de "autoridade" e tem algo a dizer - uma verdade a transmitir, uma lição a comunicar. Por isso mesmo, adotando de modo geral a postura de demiurgo, esse autor não se coloca em sua obra. A partir do Romantismo, que se propõe como valorização do indivíduo e como "liberalismo em literatura", muda essa perspectiva do autor, que geralmente passa a representar-se através de um narrador implicado no texto de for- ma autodiegética, homodiegética ou mesmo heterodiegética.

A conseqüência dessa introdução na obra de um "representante da representação" revela-se afinal uma valorização do leitor e do significante, em detrimento do autor e do significado, colocando-se em dúvida a perspectiva que vê a literatura exclusivamente como mimese, reprodução da realidade. Passa-se a preferir vê-la também como produção, linguagem, modo peculiar de se for(mul)ar um universo, considerando-se a própria linguagem um mundo. Além disso, a presença do "eu" enunciador acaba por evidenciar a necessidade de um " $\mathrm{u}^{\text {" }}$ receptor, que se constitui como complemento textual do narrador e confirma o texto como um exercício de linguagem.

O autor literário parece abdicar, assim, de sua posição de autoridade que sabe e pode ensinar, e equilibra o seu (não) saber com a capacidade de percepção do leitor, a partir da consciência de que somente esse outro pode tornar real a existência de sua obra e, afinal, a sua própria existência, o que acaba por valorizar, em primeiro lugar, a comunicação.

\section{ROMANTISMO E IRONIA}

As bases do Romantismo são os pressupostos de liberdade, liberalismo, igualdade, e a revolta do individuo contra uma sociedade que o ignora na sua subjetividade e na sua individualidade, condenando-o a reprimir seus desejos e emoções, em nome de valores morais absolutos baseados em Verdade e Bem previamente estabelecidos por governo, Igreja ou família. Essa valorização romântica do indivíduo gera entretanto um paradoxo, porque ao lado do desejo do absoluto, o homem toma consciência de sua transitoriedade e relatividade; opondo-se à infinitude de seu desejo, o homem conhece a finitude da vida. No Romantismo o sujeito assume o eu, recusa o típico em favor do único. Não pode, entretanto, deixar de criticar essa visão, num ambiente em que se desenvolvem as teorias evolucionistas, herança recusada, mas não invalidada, do racionalismo setecentista. 
Para o artista, esse paradoxo apresenta-se simultaneamente como necessidade e como impossibilidade de relato completo da realidade, o que é resolvido através da presentificação na obra de um eu enunciador, que admite abertamente o caráter ficcional de sua obra e a relativiza, libertando sua criação em sua própria esfera de realidade. A ironia será portanto um artifício através do qual a obra literária revela a consciência de ser uma construção que depende de um leitor para se tornar realidade.

Assim denominada por ter adquirido foros de cidadania em fins do século XVIII, a ironia romântica coloca em crise a literatura como representação e/ou crítica da realidade, como busca de resposta a questões e como tentativa de atingir o absoluto. Na época do Romantismo, através da conquista da autonomia formal, o autor começa a demonstrar sistematicamente que não só é capaz de apresentar-se dentro de sua obra - como fizeram Shakespeare e Cervantes - , mas que também toma consciência de ser o veiculador de um código mimético que a poética de certa forma impusera, sendo ainda o criador de um "organismo", que só existirá plenamente a partir da comunicação.

A solução para os problemas resultantes do reconhecimento do eu e da opinião individual aparece assim na valorização do outro e na busca do dialogismo, através da ironia, que se manifesta no texto a partir de contradições e/ou contrapontos, distanciamento e busca de equilíbrio. A ironia não será portanto apenas uma expressão de termos incompatíveis entre si, mas o resultado de uma atitude crítica, que dará um tom especial a toda a narrativa. Através da ironia, o Romantismo deixa de ver a obra como imitação, para vê-la como invenção da realidade: o eu se apresenta dramatizado e dividido, manifestando-se através de um redimensionamento do tempo, da consciência da representação, da duplicidade e da ambigüidade entre afirmação e negação.

$\mathrm{Na}$ ironia romântica não são apenas as narrativas como tais que são irônicas, mas é o sujeito que as enuncia que assume atitude ironicamente crítica com relação ao mundo, a si próprio e ao que cria. Ao reconhecer aspectos da outridade de distintos sujeitos no sujeito individual, a ironia estilhaça o isolamento ao qual a auto-consciência aparentemente condena o sujeito, que reconhece poder atingir o mais alto apenas de forma limitada e finita, isto é, dialeticamente, através da ironia.

A ironia romântica apóia-se na retórica clássica, na medida em que utiliza a inversão do sentido do dito com fins partidários e esconde a opinião do enunciador, que representa positivamente a opinião de seu adversário, através de um jogo de enganos cuja intenção é a luta pelo poder ${ }^{4}$. A ironia romântica amplia entretanto o conceito de ironia retórica ao estender-se a um significado metafisico; como diz Goethe, a ironia é simultaneamente dissimulação retórica e metafísica visão do mundo. A ironia romântica usa também, entretanto, a ironia humoresque ou de segundo grau, cuja intenção, diferentemente, não é dizer algo para significar o oposto, mas é manter a ambigüidade para demonstrar a impossibilidade de estabelecimento de um sentido claro e definitivo. A ironia romântica fundamenta-se ainda, evidentemente, na ironia socrática, que usa o recurso da maiêutica para levar o interlocutor à reflexão e ao conhecimento, através do processo de destruir qualquer opinião isolada por colocá-la em contato com um contexto mais amplo ou estranho e por apresentar sucessivas questões que não encontram respostas, mas vazios. Ao negar as plenitudes e as certezas, esse tipo de ato irônico abre brechas conceptuais impossiveis de preencher, criando espaço para o outro sujeito, o interlocutor ${ }^{5}$.

Os pressupostos da ironia socrática são fundamentais para a ironia romântica ${ }^{6}$, pois um autor adota atitude socrática quando menospreza os próprios talentos, parodia velhas normas, usa fingimento, representação, dissimulação e máscara. Ou ainda quando brinca com suas personagens e com o seu receptor e caçoa deles, adotando enfim um ritmo de reflexão próprio da dialética platô-
4. LAUSBERG, 1972.
5. HANDWERK, 1985.
6. BEHLER, 1988. p. 43 - 81. 
nica. $E^{\prime}$ interessante observar que a ironia de Sócrates já contém em sua essência a idéia do relativismo, pois se para o filósofo a Verdade e o Bem existiam, de forma absoluta, no mundo das Idéias, somente após 10.000 anos e sucessivas reencarnações o homem poderia ter acesso a esse mundo.

Schlegel foi o principal dinamizador da ironia romântica, a partir do reconhecimento de que o homem aspira ao absoluto, mas percebe que o abismo entre o Absoluto e a mente que busca realizálo, e ao realizá-lo compreendê-lo, é completo e definitivo: embora perceptivel, o Absoluto não é concebível ou explicável, pois tensão, contradição e oscilação são a essência da vida e somente a ironia pode responder a essa irrealizibilidade do Absoluto ${ }^{7}$.

A ironia romântica é assim o resultado da percepção do homem de sua incapacidade de exprimir com palavras e transformar em linguagem a abundância do divino, como seu espírito o percebe. A consciência disso aparece na obra através da emergência de uma voz enunciadora, procedimento irônico com que, de certa forma, destrói-se a ilusão de espontaneidade da criação artística, isto é, revela-se o trabalho em que se empenha o criador do texto, num esforço de que resulta a sua obra. A parábase leva o autor a apresentar-se numa flutuante e mediadora posição entre entusiasmo e ceticismo, o que impede o leitor de tomar como absoluto, como verdade, aquilo que the é apresentado, e que é fragmentário, incompleto e relativo, dependente de um receptor para adquirir vida.

7. Além dos textos do próprio Schlegel, existem esclarecedores estudos sobre a contribuição desse autor à questão da ironia romântica. Cf. FINLAY. The romantic irony of semiotics, 1988.

Um importante capítulo desse estudo, que acompanha a discussão entre Hegel e Schlegel sobre o assunto e esclarece questões como a da arte como sistema e como comunicação, foi traduzido pelo grupo que pesquisa a ironia na literatura na UFMG. Trata-se do capítulo intitulado: "Ironia, a iconoclasta - a crise da representação".
$O$ ressurgimento do interesse pela obra de Schlegel, na atualidade, sugere que a teoria da ironia romântica antecipou muitos dos temas centrais dos debates críticos atuais, como o das relações entre discurso e autoridade, ou entre sujeito e comunidade. É interessante observar, por exemplo, que a ironia romântica aproxima-se das reflexões de Nietzsche e de sua premissa de que a existência permite infinitas e mutuamente exclusivas interpretações, sendo a sua intenção de perspectivas reversas claramente antecipada por Schlegel e ligada ao seu entendimento da ironia. Como Nietzsche, Schlegel estava convencido de que oposição, contradição, antinomia e antíteses são essenciais para a existência do homem, sendo esse conhecimento, por sua vez, fundamental para uma educação verdadeiramente filosófica. Já Marx viu o ritmo da ironia em Schlegel como uma constante alternância entre criação e destruição, e formulou em sua tese de doutorado uma noção de ironia romântica que, em sua estrutura lógica, tornou-se mais tarde sua dialética revolucionária.

A ironia romântica tem como pressupostos a reformulação consciente do fazer literário e o questionamento desse fazer, através de constante construção/destruição da ilusão ficcional. Reformula-se o conceito de inspiração, que de sopro divino passa a sopro vital; o texto revela sua preocupação com o receptor e procura demonstrar seu caráter de arte \& manha - artifício, trama, construção. De grande auxílio para isso são os temas do teatro, do carnaval, da máscara e da consciência do jogo, usados com extrema perícia pelo ironista Camilo Castelo Branco, que formou, juntamente com Almeida Garrett e Alexandre Herculano, a tríade que melhor uso fez da ironia romântica em Portugal.

\section{O IRONISTA CAMILO}

A ironia é o vírus de liberdade que acomete Camilo Castelo Branco, vírus que o imuniza e simultaneamente o perverte, para que raramente se deixe exaltar por um sentimentalismo extremo: ao recusar o encantamento pleno, preserva-se do total desencanto, através de uma lucidez que tem pa- 
rentesco próximo com o trágico. Camilo lê com fina ironia a sua época, criticando uma sociedade em crise, o obscurantismo religioso e o despreparo de seu povo para o exercício do espírito constitucional e da economia industrial e agrícola. Registra essa leitura com uma pureza de vernáculo da qual se ri, algumas vezes, numa crítica dirigida também a si mesmo e à sua obra, manifesta no enunciado desta e na explícita consciência da enunciação de seu texto.

Para Jacinto do Prado Coelho ${ }^{8}$, várias novelas de Camilo são exclusiva ou predominantemente irônicas, e ele as separa em dois tipos: de um lado Coração, cabeça e estômago e $A$ queda dum anjo, obras de ironia mais reflexiva, mais elevada e sutil, que põe em causa problemas morais e literários experimentados pelo autor. De outro lado enfileira $A$ filha do arcediago e Aventuras de Basilio Fernandes Enxertado, "obras em que avultam a farsa, a graçola e o cômico dos caracteres": Como obra intermediária apresenta "A sorte de preto", a primeira novela de Cenas da foz, em que há uma anedota picante, mas também páginas de troça ao espiritualismo e à retórica românticos, a que o autor tantas vezes aderiu. A essas obras eu acrescentaria, entre outras, Vinte horas de liteira, com sua leveza enganadora, sua reversibilidade e complexidade das funções de narrador e receptor, sua desmistificação dos artifícios para seduzir o leitor e seu jogo constante com a (in) credibilidade do texto.

A ironia é um ingrediente tão importante na obra de Camilo Castelo Branco que mesmo obras graves como as novelas passionais Carlota Angela, Amor de perdição, $O$ que fazem mulheres e $O s$ brilhantes do brasileiro apresentam incongruências irônicas que chegam a provocar o riso, mas antes de tudo chamam a atenção do leitor para o laborioso trabalho de criação com que elas são construídas.

Um dos principais artifícios da ironia camiliana consiste no uso do ingrediente amoroso para seduzir e prender o leitor. As histórias de amor, ge-

8. COELHO, 1981. p. 351. ralmente infelizes, camuflam a sátira a uma sociedade preconceituosa e hipócrita, preocupada com o prestígio, movida pelo dinheiro e pelos interesses pessoais, desdenhosa daquilo que Camilo esbanja: leituras, cultura e, especialmente, conhecimento profundo da língua portuguesa.

A sátira camiliana fustiga, por exemplo, o desejo de bens materiais, o proveito tirado do dinheiro e dos títulos nobiliárquicos, as injustiças feitas aos jovens mais pobres de bens e de nascimento, e também a sensualidade, o ódio e a rivalidade reinantes nos conventos, supostamente lugar de fraternidade e de amor. Denuncia ainda constantemente a máscara, a mentira e a retórica balofa dos discursos políticos, das propagandas eleitorais, dos processos jurídicos, das peças jornalísticas.

A presença de elementos de representação e fingimento na construção de discursos e na descrição de situações, ambientes e personagens que retratam a época, indicam a existência da ironia também no âmbito da enunciação, fazendo com que o leitor mais avisado perceba no texto a presença de uma voz enunciadora que abre os bastidores de sua obra e exibe a arte \& as manhas de sua criação.

A ironia de Camilo em $A$ queda dum anjo transparece portanto nos dois planos da narrativa: do mundo narrado, que configura o plano do enunciado, do discurso de personagens mergulhadas numa ideologia e sem visão crítica sobre ela; e da enunciação, em que um narrador/autor comenta a narrativa, interferindo no desenrolar dos acontecimentos e comentando-os para desmistificar a sua significação e revelar o trabalho criador que constrói o texto.

A atuação da ironia reside principalmente no entretecer dos dois planos: ao mesmo tempo que refere a história ostentando seus privilégios de demiurgo, o narrador/autor apresenta-se como encenador do drama e articulador da história, e ao colocar na narrativa personagens ingênuas e/ou narratários incapazes de decodificar corretamente a ironia nas mensagens recebidas, alerta o leitor para a necessidade de uma leitura atenta do texto 
que, embora pareça reproduzir a vida, é criação, tessitura, jogo, arte.

\section{A SÁTIRA SOCIAL PRESENTE NO TEXTO}

A primeira forma de ironia que se detecta em $A$ queda dum anjo é a da sátira que se dirige ao contexto focalizado, realizada através do uso de recursos criticados na sociedade, como o fingimento e a máscara: toda a novela se estrutura como uma representação em preparação e/ou em andamento, como se pode observar, por exemplo, no cuidado com que Calisto prepara o cenário de seu primeiro encontro com Ifigênia e depois o seu ninho de amor, na casinha em que os livros pareciam mais próprios para contemplação que para leitura. Nessa casa os jardins eram um lugar especial para os passeios rituais do casal enamorado, que assim se exibia diante de curiosos espectadores. Também Lopo da Gamboa representa diante da prima Teodora, a "leitora" ingênua que não percebe o fingimento do interesseiro primo. Há muitas vezes a indicação de espectadores para as cenas: no "teatro" do parlamento as pessoas entram com bilhetes, apreciam a ação e aplaudem e/ou vaiam ou cochilam, quando entediadas. Quando Calisto vai a Campolide ver Adelaide, acaba por constituir-se em espectador da cena em que dialogam a amada e Vasco da Cunha, o que lhe revela que Adelaide o considera atrevido, hipócrita e bruto. Ao assistir ao diálogo, Calisto percebe que sua hierofante nos caminhos do amor não só não o ama mas ama o seu rival, que não está apaixonado por ela mas pelos vínculos da tia Quitéria, e em função desse amor representa sua religiosidade.

Dois são os espaços de representação privilegiados pela ironia na novela: a família e o parlamento. Quanto ao primeiro, basta observar-se a vida conjugal de Calisto e Teodora, resultado de uma união por interesse e em que não existe a comunicação; a preocupação da família do desembargador Sarmento com a opinião alheia; o cuidado de Calisto em manter as aparências, voltando toda noite para o seu hotel, depois de montar casa para Ifigênia e de passar o dia com ela. Essa volta para o hotel é especialmente interessante depois que o casal vai ao teatro - espaço privilegiado de representação - , tomando depois distintas carruagens para recolher-se a casa.

O parlamento é visto com um espaço onde se encena uma democracia, fingindo-se preocupação com o país. Fazem-se ali juramentos que se sabem apenas formais, bem como discursos inflamados, cuja intenção é dominar pela ironia retórica, estabelecendo-se uma relação de poder, com definição de dominadores e dominados. Nesses discursos, o objetivo não é defender uma idéia e um beneficio para o povo, nem mesmo um programa partidário, mas apenas fingir fazê-lo para vencer o oponente através da força da palavra, usada muitas vezes sarcasticamente, isto é, com uma ironia aberta e agressiva.

O parlamento tem até o aspecto de um teatro, onde as pessoas vão para distrair-se de "pensares melancólicos". Alguns espectadores dormem enquanto outros se divertem ou comentam, há risos e aplausos e "farfalhices", sendo também o debate uma representação que permanece no âmbito filológico, como diz o próprio deputado Benevides de Barbuda. Os discursos revelam uma luta retórica, em que a função de deputado serve apenas como oportunidade de exibição de conhecimentos, com o que pretende cada um elevar-se a partir do desmerecimento da figura do outro. O Dr. Libório é acentuadamente ridicularizado: além de atribuirlhe discursos retóricos e vazios, o narrador conta que ele foi reprovado em latim e vingou-se dos examinadores: impelido pelo "coice de Pégaso",

traduziu um poema latino com tanta clareza e fidelidade, que o poema original ficou sendo muito mais inteligível aos ignorantes de latim do que a versão com que a memória de Lucrécio fora ultrajada (p. 66).

$\mathrm{E}^{\prime}$ interessante observar que o narrador ausenta-se dos diálogos parlamentares, substituindo-se por marcações entre parênteses e/ou em itálico, o que resulta em mais vivacidade da cena e explica as 
várias vezes que o texto de $A$ queda dum anjo foi adaptado para teatro.

Ligam-se a essa questão da representação as várias situações, na novela, em que leitores ou espectadores ingênuos são enganados pela ironia de espertos "atores" ou por sua leitura deficiente: Teodora é seduzida pelo primo Lopo de Gamboa; Duarte Malafaia confirma sua ingenuidade quando acredita no papel representado por sua esposa; o mestre-escola e o boticário são adulados/enganados por Calisto Elói, que é enganado pelas gentilezas com que Adelaide o trata; Adelaide é trapaceada por Vasco da Cunha, que tenta roubar a amada de Calisto Elói, cuja "honradez" engana o comendador Sarmento, que depois engana Calisto, mandando as filhas para a quinta de Campolide, sem avisá-lo.

Em vários momentos a novela se caracteriza como uma farsa, a que não falta o elemento ridículo: Teodora é apresentada como "(...) ignorante mais que o necessário para ter juízo" (p. 52); nem sabe onde é a Europa (p. 253); é "mais feia do que pede a razão que seja uma senhora honesta" (p. 103); suas "toucas e lencinhos pudibundos não são enfeites muito sedutores e, além disso, tornam a virtude rançosa (p. 154); quando chega à conclusão de que já não tem marido, conta o narrador: "Acocorou-se no chão a chorar, com a cara metida entre os joelhos" (p. 227). Os paroxismos de seu desespero quando se vê ameaçada de perder o marido fazem-no comentar: "Ora acabemos com esta feia comédia, e manda-me preparar jantar, que preciso comer e dormir" (p. 225). Apesar de sua descrição, entretanto, e acentuando o caráter de representação do texto, a personagem é posteriormente transformada em tal beleza que até seu pé fica menor: adquire, no andar, um "certo requebro e donaire que lhe ia tão natural como se tivesse sido educada por salas e adestrada em flexuras da dança" (p. 257-8). Essas mudanças indicam também transformações mais profundas na personagem: seduzida pelo primo Lopo, ela passa a tirar peças de seu caixote de ouro, ao invés de estar apenas preocupada, como antes, em acrescentar-lhe outras moedas. Acentuando além disso uma vez o seu caráter de títere, Teodora diz a Lopo que o teria amado, se tivesse se casado com ele.

Também o professor de instrução primária é bastante ridicularizado: além de chamar a atenção para as suas orelhas, o narrador conta ter ele ficado ruminando as palavras do fidalgo, após aquele discurso no adro da igreja, em Caçarelhos, ou mostra a ingenuidade da personagem que procura o deputado de Miranda no paço real, em Lisboa. Conta também que na conversa com Teodora, que estranhava a atitude do marido, Brás Lobato fez "com os beiços um bico e logo um arco, trejeitos meditabundos com que ele ousava solenizar os dizeres graves" (p. 202).

Vale a pena, aliás, observar de perto a construção de algumas personagens da novela, como o "anjo humanizado", o "lobo dissimulado" e a "brasileira" de Portugal.

Calisto Elói de Silos e Benevides de Barbuda, o protagonista de $A$ queda dum anjo, é o anjo humanizado, cujo nome pomposo é compatível com sua fortuna e tradição de herói, afirmadas através de sua ascendência nobre, de seu saber livresco e de suas riquezas, que são garantidas pela união dos dois morgadios e pela boa administração da esposa Teodora. Calisto é entretanto um herói ridículo por seu aspecto físico, por estar preso ao passado e por seu comportamento, pois enfrenta monstros quixotescamente. Além do já mencionado anacronismo de suas vestimentas e de seus discursos, observa-se que os sintomas de seu estado amoroso são relacionados a elementos fisiológicos, o que os torna cômicos: quando viu o coraçãozinho de prata e ouro de Adelaide, "o morgado de Agra das Freimas sentiu do lado esquerdo do peito, entre a quarta e a quinta costela, um calor de ventosa (...) (p. 105); sua paixão manifesta-se também pela "queda da espinhela", sensação esquisita de vácuo e despego (idem). Quando tem a desilusão com Adelaide, sente algo que the define o espírito, segundo o narrador, e que o leitor descobre ser fome, já que em seguida ele faz uma refeição de presunto e ovos, regada a vinho. Quando conhece Ifigênia, Calisto leva maquinal- 
mente "a mão ao coração: traspassara-lho uma azagaia eléctrica" (p.176). E o narrador ironiza a transformação que o amor opera na personagem:

Aquela alma vai-se transformando à proporção da roupa. Assim como o leitor, à medida que o amor lhe fosse avassalando o peito, escreveria páginas íntimas, ou ainda pior, cartas corruptoras à mulher querida, Calisto, em vez disso, muda de calças. (p. 126).

A construção irônica de Calisto Elói marca-se também pelo exagero: sua memória é tão prodigiosa que é capaz de lembrar, entre os seus clássicos, das obras de doze Petrônios e de "todas" as mulheres fatais, em que se incluem personagens da História, da Bíblia e da literatura; também as transformações que se operam na personagem são quase inverossímeis: depois delas o morgado abandona sua rigidez moral e política, pára de querer reformar o mundo, embeleza-se a partir do cuidado com seu físico e sua mente e, principalmente, passa a ter um discurso pragmático de frases curtas e objetivas, em que comparece muito mais o silêncio que a palavra.

Calisto é inicialmente vítima da ironia pela ingenuidade de suas leituras, que não atentam para a necessária contextualização de seus clássicos, o que tem como resultado os seus primeiros problemas em Lisboa, por exemplo com a água. Sua leitura deficiente engana-o ainda quando o leva a supor que Adelaide o ama, embora ela declare apenas a estima que lhe tem (p. 104 - 5), e também quando agradece ao lobo da gamboa, que lhe ronda a fortuna, o aviso sobre a viagem da esposa, chegando a dizer-lhe que pretende pedir o divórcio e a separação do casal; anuncia assim ao rival, ingenuamente, a sua vitória na empresa de ficar com o desejado dom de Deus, Teodora.

O deputado por Miranda trouxe de Caçarelhos habilidade retórica para lutar com opositores, como revelam as suas contendas com o Dr. Libório e os episódios das botas, das luvas e da "salvação" de Catarina Sarmento; mas é só depois de "aprender a ler a realidade" que ele se integra ao seu tempo e é capaz de amar, de ter desejos e de ser feliz: torna-se capaz até de vencer os rivais que lhe rondam a bela Ifigênia, objeto de seu desejo.

Vale a pena notar que Calisto cura Catarina de sua infidelidade conjugal para depois contrair a mesma "doença", o que o leva a uma ciranda amorosa; enamora-se da irmã da adúltera catequizada, a qual busca o amor de Vasco da Cunha, que por sua vez espreita a sua amada Ifigênia.

Já a personagem Lopo de Gamboa é, desde o início, capaz de lutar ironicamente pela realização de seu desejo: lobo dissimulado, ele fica no remanso tranqüilo da gamboa, tecendo cuidadosamente a sua intriga para apanhar a prima Teodora, que parece o chapeuzinho vermelho da história infantil, com seu lenço de três pontas ou com seu "fatal chapéu, que é um monstro de palha" (p. 243). A ocasião para a conquista da prima (e de seu caixote de peças de ouro) surge quando Calisto mudase para Lisboa e apaixona-se por Ifigênia. Lopo consegue então seduzir Teodora, com o auxílio do próprio marido desta, pois tece espertamente a sua trama irônica e aparenta batalhar pela realização do desejo de ambos, a fim de atingir realizar o seu: finge para a prima que trabalha para trazerlhe o marido de volta, e para Calisto finge ajudálo a livrar-se da esposa, o que afinal é verdade, embora não como julga o deputado, que recomenda: "Primo Lopo, olha tu se dás juízo a tua prima" (p. 233). Lopo de Gamboa representa especialmente diante de Teodora: quando esta lhe pergunta o que deve fazer, depois de ouvir a sua declaração de amor, ele responde com veemência: "Matar-me! (...), deixando cair os braços, e descendo ao chão os olhos amortiçados" (p. 220). Chega a esborrachar os olhos para eles verterem água, para assim comprovar sua paixão (p. 219), ou então contém "o impulso de desfechar uma risada na cara da prima", em nome da "coerência do seu plano" (idem).

Outra personagem adaptada ao seu tempo e hábil tecedeira de tramas irônicas é Ifigênia, que nasceu e casou-se no Brasil e confirma a tradição da no- 
vela camiliana em que o brasileiro é elemento de transformação na sociedade portuguesa. Ironicamente, a "brasileira" faz a fortuna em Portugal e não no Brasil: culta, fina, inteligente, nascida com o poder - é o significado do seu nome - ela tem a força de sua própria natureza e, por isso, é capaz de transformar Calisto e torná-lo um amante dócil que usa os cordões da bolsa bem desapertados. Ifigênia é uma brasileira que não tem dinheiro, mas sabe onde encontrá-lo; além de personagem, é uma narradora convincente que comove um Calisto endinheirado que poderia representar o Brasil, no sentido de ser onde se poderia facilmente fazer fortuna.

$E^{\prime}$ interessante notar que, ao comentar a felicidade de Calisto pelo amor de Ifigênia, o narrador faz observações aparentemente descabidas sobre a questão da fortuna, as quais parecem acabar por sugerir que a bela viúva não buscava propriamente a proteção e a amizade do marido de Teodora, mas de seu dinheiro e prestígio.

\section{ARTE \& MANHAS DA ENUNCIAÇÃO}

$\mathrm{Na}$ advertência à segunda edição de $A$ queda dum anjo, o autor lamenta que a pressa com que foi pedida a revisão do livro tenha impedido que a nova edição viesse acompanhada de notícias recentes das personagens. Promete um romance novo, se a colheita fornecer elementos para um outro volume, e informa que talvez a terceira edição venha à luz acompanhada de fotografias. Já nessa promessa de acréscimo de documentos à terceira edição aparece portanto a ironia da enunciação em $A$ queda dum anjo: é como se o enunciador do discurso falasse com um leve sorriso ou uma tongue-in-cheek intrigantes, capazes de prender o leitor e de garantir a sua atenção, que é afinal o que vai dar vida ao texto da novela.

Também a referência às cortes de Lamego (p. 12) constitui um sinal de ironia, pois lembra que documentos forjados e de interesse específico podem ser apresentados como verdade para garantir um desejado sentido conferidor de poder ${ }^{9}$. Funciona, assim, como irônica piscadela de um autor que busca a cumplicidade de seu leitor, o qual deve fingir aceitar como verdade o que é literatura, jogo, mas também comunicação entre dois sujeitos que se entendem através da linguagem.

Há momentos em que o narrador explicita o seu estatuto de criador de mundos fictícios:

Da maior, e talvez única dor literária da sua vida, fui eu causa. Calisto, pernoitando em não sei que solar de damas dadas à leitura amena, pediu algum livro, e deram-lhe um romance meu. Consta-me que deixou o volume com as margens anotadas de galicismos e manchas de toda a casta. Imaginem quantas punhaladas eu dei naquele lusitaníssimo coração! (p. 79)

Isso acontece também no final da novela, onde afirma o narrador, referindo-se a Calisto Elói: "Eu, como romancista, lamento que ele não viva muitíssimo apoquentado, para poder tirar a limpo a sã moralidade deste conto (p. 264). Assinala assim a diferença entre vida e criação literária, reafirmando que o que faz é literatura: "A natureza de Sintra, incluindo os rouxinóis daquelas ramarias, poderia espantar-se: eu, não" (p. 192). Assume ainda a postura de articulador da narração por exemplo quando se recrimina:

9. As Cortes de Lamego forjaram, no cartório do Mosteiro de Alcobaça, onde os monges especializavam-se em estudos históricos, um documento cujo original dataria do século XII e cujo objetivo seria excluir da sucessão legítima da coroa portuguesa os reis castelhanos e espanhóis. Incongruências como a referência à representação popular muito antes que ela fosse possível e a presença de cláusulas que só poderiam ter sido formuladas no século XVII, além de deficiências formais reveladoras da ignorância diplomática de seu autor, transformaram esse documento em um exemplo de texto construído pela retórica irônica: sua intenção é enganar, garantindo uma significação e um poder, que podem entretanto ser desconstruidos e esvaziados por uma leitura atenta, que transforma o enganador em enganado. 
Vamos já rodeando por longe os ciúmes de Calisto Elói. Revertamos ao assunto (p. 197).

O narrador afirma diante do narratário sua autoridade sobre a narração que faz: "Não me acoimem de arquivista de insignificâncias. Este pormenor das calças prende mui intimamente com o cataclismo que passa no coração de Barbuda" (p. 126). No mundo fíctício criado tudo é possível, por isso mesmo refuta possiveis desconfianças do leitor, quando sugere o amor de Ifigênia por $\mathrm{Ca}$ listo Elói: "(...) lisonjeou-se? Não sei com que direito me fazem essa pergunta assim com uns visos de espanto!" (p. 195). Confirmando o estatuto de criação de seu texto, o narrador/autor assume que suas personagens são inventadas: reconhece o caráter ficcional de sua novela, relacionando-a às leituras de Ifigênia, ou denuncia as jogadas irônicas de Lopo e afirma que ele é um dos elementos da corja de birbantes ${ }^{10}$ de suas novelas. Há também momentos em que essa voz enunciadora reconhece o caráter inverossímil dos fatos narrados:

$\mathrm{O}$ inesperado remate desse diálogo figurouse-lhe a ela a passagem de um romance, que se não preza de muito verosímil. Porém como quer que a viúva do general Ponce de Leão fosse grandemente lida em novelas francesas, o caso não lhe pareceu tão extraordinário como ao leitor e a mim, quando mo referiram (p. 185).

Entre os exageros indicadores de ser ficcional a narrativa poder-se-ia indicar a concentração de muitos acontecimentos em pequeno espaço de tempo, de que é exemplo a manhã em que Calisto sai de casa, compra alfaias magníficas, prepara a sala para esperar Ifigênia, recebe e lê carta de Teodora e lhe responde. $O$ mesmo se poderia dizer sobre a cena do primeiro encontro de Calisto e Ifigênia, que contam em poucas horas um ao outro toda a sua vida e se entendem às mil maravilhas.

10. Birbantes são patifes, velhacos (p. 244).
O texto se afirma como literatura também ao apresentar incongruência entre o que anuncia e o fato que narra, por exemplo quando prepara o espírito do narratário com alusões a episódios solenes da História de Roma, contrastantes com o que se segue: o relato do debate no Parlamento sobre a concessão de um subsídio ao teatro lírico do Porto ${ }^{11}$. Ou quando torna evidente a inadequação entre títulos e conteúdos, como já se viu em relação à novela. Isso ocorre ainda em outros momentos: nos capítulos que apresentam severos títulos em latim, contrastantes com as farsescas cenas vivenciadas nos mesmos pelas personagens, ou nos títulos ultra-românticos de alguns capítulos: "Tentação! Amor! Poesia!", "Quantum mutatus!", "Vai cair o anjo!", "E ela amava-o!", "Como ela o amava!", "Perdida!", "Vence o demônio!, Choram os anjos!" Essa estranheza se acentua quando se observa a diferença entre esses e outros títulos bem objetivos e/ou críticos, como: "Asneiras da erudição", "Virtuosas parvoiçadas" e "Figura, vestido e outras coisas do homem".

O narrador indica ainda que seu texto é literatura, ao usar ironicamente os antropônimos e os topônimos (lembrem-se os nomes de Calisto Elói, Teodora e Lopo de Gamboa e o da rua onde mora Ifigênia); ao afirmar num capítulo (XXXI) que o saco de peças, pecúlio de Teodora, tinha sido trazido para a família Travanca por seu bisavô, governador do Brasil, para dizer em outro capítulo (XXXV) que as peças teriam vindo com o governador da Índia. Mas principalmente ao apresentar a sua história com um final de conto de fadas, em que os amantes tiveram filhos (que vieram da França numa condessinha) e foram felizes para sempre, ou ao colocar-se como aquele que reproduz histórias ouvidas, igualmente fantasiosas: "Ouvi rosnar que no solar de Travanca também apareceu um repolhudo menino, que, pelos modos, também veio no cesto de alguma parte" (idem).

11. Talvez se pudesse ver ai uma crítica à própria História, que também teria, como o teatro lírico, um caráter de representação. 
O caráter ficcional do texto se evidencia também ao se multiplicarem funções das personagens na narrativa: Calisto Elói é personagem, leitor incansável, narrador (especialmente quando conta sua história para Ifigênia) e narratário (quando ouve a história da viúva); é, além disso, um porta-voz do autor na obra, ao falar no parlamento contra os impostos cobrados do lavrador desprovido de recursos, ou ao fazer sérias críticas a Portugal. Teodora é personagem, leitora mais ou menos capaz de perceber a ironia presente nas cartas de Calisto, mas receptora ingênua da corte de Lopo de Gamboa. Ifigênia é personagem, narradora e narratária perspicaz da história de Calisto Elói; Lopo de Gamboa é personagem e articulador da trama que vai prender Teodora, e Catarina é personagem da história e autora e atriz do drama que representa para o marido.

O narrador se apresenta ainda como articulador de uma história construída quando registra sua presença através de categorias gramaticais, como pronomes de primeira pessoa, adjetivos e advérbios. Veja-se o exemplo da página 13:

O mal que daqui surdia ao género humano, a falar verdade, era nenhum. Este bom fidalgo, se lhe tirassem o sestro de esmiuçar desdouros nas gerações das familias patrícias, era inofensiva criatura. Deste senão, a causa ...

Ou então quando apresenta interferências modais de tempo e/ou de juízo de valor sobre os fatos narrados, com exagero de exclamações, presentes por exemplo nas linhas iniciais de alguns capítulos, como o XIII: " $O$ ' coração sensível! $O$ ' pecadora Catarina, que vais agora expiar o teu crime na cruz da saudade! Aquele Calisto, cuidando que te salvava, matou-te!" (p. 98). Ou no capítulo XIV, intitulado "Tentação! Amor! Poesia!, que assim começa: "Eis que, a súbitas, do coração de Calisto ressalta a primeira faísca de amor!" (p. 103). Ou ainda em comentários finais como o do capítulo XVI, em que o narrador adverte os maridos de mulheres como Teodora:
Ai! maridos, maridos! Quando a Providência vos enviar mulheres deste raro cunho, encostai a face ao regaço delas, e não queirais saber como é que o inimigo de Deus enfeita as suas cúmplices na perdição da humanidade!

O narrador de $A$ queda dum anjo assume a sua função irônica também através de outros comentários: após o desastre de Campolide, em que Calisto descobre que sua amada Adelaide ama Vasco da Cunha, depois de mencionar os conquistadores que se vingam em mulheres inocentes quando recebem a "ingratidão injuriosa de mulheres muito amadas", diz: "Que tristeza! E ninguém fala disto senão eu, porque me cumpre fazer o elogio de Calisto Elói, que não fez coisa nenhuma daquelas" (p. 169). Mais interessante fica ainda o comentário, se se observa que a personagem vai em seguida preparar sua sala para receber a bela Ifigênia, numa clara sugestão de expectativa de adulterinos amores.

Um dos sinais de ironia em um texto são as mudanças de registro com conseqüente esvaziamento da seriedade, o que ocorre ao se misturarem, por exemplo, o sentimental e o que se refere a questões físicas, características humanas e animalescas. $\mathrm{E}^{\prime}$ o que se vê, por exemplo, quando Calisto fica atônito ao saber que o Estado subsidiava o teatro de São Carlos: "Ao espanto, cólera e dor de alma seguiram-se cãimbras nas pernas" (p. 41); ou quando depois de muito valorizar o amor, o narrador o compara à tênia, já que os sintomas de ambos não seriam descobertos pelas pessoas inexpertas (p. 124); ou ainda quando o boticário e o mestre-escola são vistos como orelhas (p. $17 \mathrm{e}$ 19) que, junto com os lavradores, ficaram ruminando as palavras do fidalgo.

O esvaziamento irônico da seriedade sinaliza-se em $A$ queda dum anjo ao colocarem-se lado a lado elementos incompatíveis: o Soneto V, de Antônio Ferreira, adequado ao sentimento amoroso que domina Calisto Elói, e a carta da esposa Teodora, que fala prosaicamente em barrosãos, vacas de cria, cevados, porca ruça, leitões e carros de 
centeio, e ainda de "mal de reins" e de estar "despegada do peito"; as causas da mudança de Calisto: - "E a não ser o amor, que poderia ser senão as calças de xadrez? (p. 121-2). Depois de sua viagem a Lisboa, Teodora "(...) cuidou em reparar as forças com um dormir daqueles que a Providência concede às consciências puras e às pessoas que desembarcam enjoadas" (p. 234); sua virtude é "rançosa" (p. 154) e ela "encaixota" o corpo na liteira para ir a Lisboa. O mestre-escola de Caçarelhos não distinguia entre autonomia nacional e anatomia nacional, e conseguiu convencer o seu partido político, ganhando-o de "eloqüente assalto", não tendo entretanto ficado despremiada sua "verbosidade" (p.21).

Há momentos em que $A$ queda dum anjo faz paródia de novelas passionais do próprio Camilo Castelo Branco: quando Calisto Elói vai à procura de Adelaide na quinta de Campolide, a narrativa parece lembrar episódio semelhante, que está na novela passional Amor de perdição. Trata-se da visita de Simão a Teresa, na qual há também um triângulo amoroso e da qual resultam o ferimento de Simão e a morte de um aliado de seu rival Balthazar. Assim se inicia a cena em $A$ queda dum anjo:

Aquela hora, e por aquela noite capeadora de assassinos e bestas-feras, Calisto Elói, embrulhado num capote de três cabeções e mangas (...) passava rente com o muramento da quinta de Adelaide (p. 152).

Depois desse intróito prenunciador de tragédias, o narrador conta que a personagem se distrai com suas lembranças literárias enquanto espera, até que Adelaide e Vasco da Cunha chegam à janela, e Calisto ouve sua amada chamá-lo atrevido, hipócrita e bruto, declarando em seguida o seu amor a Vasco.

Enquanto em Amor de perdição as personagens "vivem" o seu amor em cenas trágicas, em $A$ queda dum anjo o "apaixonado" parece apenas assistir a uma representação: imediatamente após sua desilusão amorosa vai para casa com uma es- tranha sensação que o leitor descobre ser de fome e faz uma boa refeição preparada pela viúva do tenente de infantaria, a qual na oportunidade lhe declara sua admiração, contando além disso que a vizinha do primeiro andar se interessa por ele e que a bela Ifigênia o procurou e voltará no dia seguinte. Ironicamente, o protagonista frustrado em seu amor torna-se um galã desejado pelas mulheres e passa a assumir um novo papel na representação.

Os sinais da comunicação irônica obedecem a um código particular: não se dirigem ao objeto da ironia, mas a uma terceira pessoa, presente real ou supostamente ao ato da palavra irônica. $\operatorname{Em~} A$ queda dum anjo há várias piscadelas desse tipo, como os comentários entre parênteses (ou não) que mostram contar o narrador com a atenção do leitor: quando o mestre-escola discursa sobre a necessidade dos impostos, e afirma que, sem eles, não haveria rei nem professores de instrução primária, segue-se: "(observem a modéstia da gradação!)" (p. 59); quando Brás Lobato conta a Teodora que Calisto Elói estava em perigo e que ele, professor, embora soubesse disso previamente, ter-se-ia deixado erroneamente convencer pelos abades e lavradores a eleger Calisto Elói, lê-se: "(O impostor que tinha votado em si!)" (p. 198); após a narração do início de vida conjugal de $\mathrm{Ca}$ listo e Teodora, encontra-se: "Ora, deste começo de amores infiram, senhores, o restante daquela doce vida!" (p. 78); depois de referir os incessantes trabalhos domésticos de Teodora e as leituras constantes do marido, algum tempo após o enlace, afirma com ênfase o narrador: "Vida para invejar! Paraíso em que Deus se esqueceu de mandar o anjo do montante de fogo vedar a entrada!" (p. 104); e depois de mostrar que o despeito foi o motivo da mudança de Catarina Sarmento, comenta que "Ainda há gente boa e de muitíssima virtude; isto é que é verdade" (p. 101). Quando as peças de ouro de Teodora caem nas mãos de Lopo, diz o narrador que teriam sido "provavelmente adquiridas com tanta honestidade como agora iam ser esbanjadas" (p. 241) e quando a virtuosa esposa aceita a corte de Lopo, lê-se: "honra à virtude que cai mais tarde que o costume! (p. 239). 
Esses avisos irônicos parecem enfatizar que nada do que se lê é "verdade", pois as personagens seriam apenas seres de tinta e papel, e os documentos" comprobatórios de "verdade histórica" um artifício usado pela literatura que se desmistifica como representação da realidade diante do leitor, a quem se exibe como uma produção artística em que tudo é invenção, criação, elaboração de linguagem.

Confirmando afinal ser a sua obra uma construção artística que se elabora conscientemente como arte, o narrador de $A$ queda dum anjo exime-se de apresentá-la completa: "Eu, como já disse, não sei realmente se lá no recesso daqueles arcanos domésticos há borrascas" (p. 245). E termina afirmando não ter a sua história nenhum objetivo que a transcenda: "Fica sendo, portanto, esta coisa uma novela que não há de levar ao céu número de almas mais vantajoso que a novela do ano passado" (p.245).

Através desses elementos o narrador exibe-se ao leitor como um escritor em ação, a indicar marotamente os fios com que tece a sua novela, que é colocada como resultado da produção de um artista que pode ligar o amor ao casamento ou fazer as personagens realizarem $o$ amor independentemente da convenção social, pois é ele quem constrói a obra. A partir da liberdade de que dispõe para manipular os ingredientes, pode inverter ironicamente uma fórmula já anteriormente utilizada com êxito, para assim realizar um texto que não se coloca apenas como simples representação ficcional da realidade, mas também como o contar uma história, com o autor e a narração, o leitor e a leitura, o estilo e sua escolha, a ficção e o fato, a partir de uma perspectiva em que o autor deixa de ser potencialmente o "dono da verdade" para, através de um descentramento intencional do ser, operador de uma abertura para o outro, realizar a verdadeira comunicação que se apoia no reconhecimento desse outro como sujeito.

Em A queda dum anjo ironiza-se, portanto, o contexto representado, já que a queda não é que$\mathrm{da}$, os defensores do povo não $o$ defendem e o parlamento e a família são realmente representa- ções. Também a história contada é ịronizada, por ser apresentada como um conto de fadas que parodia as narrativas românticas. O autor ironiza ainda a construção narrativa, pois desnuda para o leitor os artifícios de seu texto, do qual mostra a tessitura transparente, que deixa ver simultaneamente o seu direito e o seu avesso. Fala portanto de ironia com ironia, o que é uma forma de buscar a compreensão reflexiva de seu leitor, com quem estabelece comunicação, valorizando-o como um outro capaz de posicionar-se criticamente diante da literatura e diante da realidade.

Seja portanto através da ironia retórica presente no enunciado da novela e nos discursos de suas personagens, da perspectiva crítica do narrador/ autor sobre as mesmas e sobre a realidade retratada, ou através de sua manifesta consciência de estar elaborando como obra literária o seu texto, $A$ queda dum anjo deixa entrever a sua tessitura irônica, com a qual, numa apurada tradição camiliana e num magnífico exemplo de ironia romântica, $o$ autor valoriza o leitor que construirá com ele o sentido do texto. Além disso, reconhece que o ser humano é condenado à impossibilidade de atingir o divino e o absoluto, mas pode encontrar no exercício artístico da linguagem e na comunicação com o outro uma ilusão momentânea de plenitude, satisfação e, principalmente, de liberdade.

\section{REFERÊNCIAS BIBLIOGRÁFICAS}

1. ALMANSI,Guido. L'affaire mystérieuse de lábominable "tongue-in-cheek". Poétique, Paris, n. 36, p. 413 - 426, nov. 1978.

2. BEHLER, Ernest. The theory of irony in german romanticism. In: GARBER, Frederick. Romantic irony. Budapest: Akadémiai Kiadó, 1988.

3. BRANCO, Camilo Castelo. A queda dum anjo. Porto: Lello \& Irmão, 1981.

4. COELHO, Jacinto do Prado. Introdução ao estudo da novela camiliana. 2 . ed. Lisboa: Imprensa Nacional/Casa da Moeda, 1981. v. 1. 
ENSAIO

5. FINLAY, Marike. The romantic irony of semiotics; Friedrich Schlegel and the crisis of representation. Berlin: Mouton de Gruyter, 1988.

6. GARBER, Frederick. Romantic irony. Budapest: Akadémiai Kiadó, 1988.

7. HANWERK, Gary J.. Irony \& ethics in narrative; from Schlegel to Lacan. New Haven: Yale University Press, 1985.

8. LAUSBERG, Heinrich. Elementos de retórica literária. Trad. R. M. Rosado Fernandes. 2. ed. Lisboa: Fundação Calouste Gulbenkian, 1972.

\begin{abstract}
Analysis of the representative elements of faking games with which Camilo Castelo Branco constructs the ironic intrigue of $A$ queda dum anjo, where he satirizes a hypocritical society, parodies his own passional novels and gives value to the reader capable of seeing that the text tries to reproduce life but, in fact, is creation, tessitura, art.
\end{abstract}

